\title{
Chapter 8 \\ Counting Ethnicity in Malaysia: \\ The Complexity of Measuring Diversity
}

\author{
Shyamala Nagaraj, Tey Nai-Peng, Ng Chiu-Wan, Lee Kiong-Hock, \\ and Jean Pala
}

\subsection{Introduction}

Malaysia has long been concerned with the ethnic dimension in its society. Today, this concern pervades all debate whether on education or politics. Indeed, it dominates coffee room discussions on any area that relates to achievement of human potential, whether in the area of human capital, physical capital, financial capital, entrepreneurship, politics or government.

\footnotetext{
This is a lightly edited version of the paper 'Counting ethnicity in Malaysia: The complexity of measuring diversity' published in the Malaysian Journal of Economic Studies, 46 (2), pp. 5-32, and reproduced here with permission of the publisher. The journal paper is a revised version of the conference paper 'Counting and integration: the experience of Malaysia' presented at the International Conference on Social Statistics and Ethnic Diversity: Should We Count, How Should We Count and Why?, 6-8 December 2007, Montreal, Canada. We are grateful to Charles Hirschman for his substantive comments and to Jomo K. S. and Vijay N. Nair for their feedback on an earlier version. However, the usual disclaimer applies.
}

S. Nagaraj $(\bowtie)$

Department of Statistics, University of Michigan, Ann-Arbor, MI, USA

e-mail: shyamnk@umich.edu

T. Nai-Peng

Department of Applied Statistics, Faculty of Economics, University of Malaya,

Kuala Lumpur, Malaysia

N. Chiu-Wan

Department of Social and Preventive Medicine, Faculty of Medicine,

University of Malaya, Kuala Lumpur, Malaysia

L. Kiong-Hock

World Bank Consultant, Kuala Lumpur, Malaysia

J. Pala

Project Consultant, Kuala Lumpur, Malaysia 
The diversity evident in the ethnic fabric of Malaysians is officially acknowledged and celebrated in Tourism Malaysia's slogan 'Malaysia, Truly Asia'. More importantly, it is a critical and powerful driver in the design and implementation of many public policies. With the multi-ethnic, multi-lingual, multi-cultural and multireligious composition of the populace, national unity remains the main stated objective of economic, social and national development. The New Economic Policy (NEP) was introduced in 1971 in response to the ethnic disturbances of 1969. Its primary objectives were reduction of poverty irrespective of race, and restructuring of Malaysian society to eliminate identification of race with economic function to reduce inequalities in income distribution between races and to reduce the identification of race with economic activities. More than three decades later, the ethnic dimensions of public policy remain important, for instance as reflected in 2007 under the National Vision Policy. ${ }^{1}$

Data on ethnicity is therefore very important for monitoring and strengthening public policies that seek to address ethnic imbalances. It is not surprising then that measuring ethnicity in Malaysia extends beyond the decennial census and is an important element in the production of official statistics. Today, it seems like information on ethnicity is collected by almost every institution, whether public or private. The question is, given the difficulty in measuring ethnicity, whether the meaning and measurement of ethnicity is the same in the different surveys and documents, and over time. This chapter examines the complexity of defining and measuring ethnicity across time and across different official documents. The most important enumeration of ethnicity in the population occurs every 10 years or so with the taking of the census. Ethnicity information is regularly obtained in other censuses (such as ethnic profile of employees in the Economic Censuses), surveys (such as in the Labour Force Survey) and as a by-product of administrative procedures (such as birth registration). The next section first provides an introduction to the diversity in the ethnic fabric of Malaysia. This is followed in the third section by an appraisal of how ethnicity is, and has been, measured in the censuses. The fourth section considers measurement of ethnicity by different agencies. The final section concludes the chapter with a discussion of the principal findings and their implications.

\subsection{Ethnic Diversity in Malaysia}

The concept of ethnicity is somewhat multidimensional, as it includes aspects such as race, origin or ancestry, identity, language and religion. As Yinger (1986) remarks, in practice ethnicity has come to refer to anything from a sub-societal group that clearly shares a common descent and cultural background (e.g., the Kosovar

\footnotetext{
${ }^{1}$ In 1991, aspects of the policy changed and were implemented as the National Development Policy (1991-2000), with a further change in thrust under the National Vision Policy (2001-2010). In the rest of this paper, we use 'NEP' to refer to these three set of policies.
} 
Albanians) to persons who share a former citizenship although diverse culturally (Indonesians in the Netherlands), to pan-cultural groups of persons of widely different cultural and societal backgrounds who, however, can be identified as 'similar' on the basis of language, race or religion mixed with broadly similar statuses (Hispanics in the United States) (as cited in Yeoh 2001).

Table 8.1 shows the population distribution by ethnic groups in Malaysia for year 2000. These categories are as different as Yinger notes, referring to groups that share a common descent and cultural background (e.g., the Chinese), persons whose parents share a former citizenship although diverse culturally (e.g., the Indians) to pan-cultural groups from different cultural and societal backgrounds broadly considered 'similar' (e.g., the Malays).

Some of the 18 groups listed here are categories summarizing the population of smaller groups. The degree of ethnic diversity in Malaysia is apparent when we examine the Ethnic Fractionalization Index (EFI), an index that measures the racial (phenotypical), linguistic and religious cleavages in society (Yeoh 2001). This index is based on the probability that a randomly selected pair of individuals in a society

Table 8.1 Malaysia, population by ethnic group, 2000

\begin{tabular}{l|l|l}
\hline Ethnic group & $\begin{array}{l}\text { Number } \\
\text { (thousands) }\end{array}$ & $\begin{array}{l}\text { Percentage } \\
\text { distribution }\end{array}$ \\
\hline Total population & 22198.2 & 100 \\
\hline Malaysian citizens & \multicolumn{2}{l}{} \\
\hline Malays & 11164.95 & 51.0 \\
\hline Kadazan Dusun & 456.9641 & 2.1 \\
\hline Bajau & 329.9529 & 1.5 \\
\hline Murut & 80.07225 & 0.4 \\
\hline Iban & 578.3544 & 2.6 \\
\hline Bidayuh & 159.5528 & 0.7 \\
\hline Melanau & 108.275 & 0.5 \\
\hline Other Bumiputera & 695.7017 & 3.2 \\
\hline Chinese & 5291.277 & 24.2 \\
\hline Indians & 1571.664 & 7.2 \\
\hline Other Malaysian & 243.3723 & 1.1 \\
\hline citizens & & \\
\hline Non-Malaysian citizen & &
\end{tabular}

\begin{tabular}{l|l|l}
\hline Non-Malaysian citizens & \\
\hline Singapore & 16.66528 & 0.1 \\
\hline Indonesia & 704.9711 & 3.2 \\
\hline Philippines & 197.9126 & 0.9 \\
\hline Thailand & 33.33057 & 0.2 \\
\hline India & 28.10418 & 0.1 \\
\hline Bangladesh & 64.09725 & 0.3 \\
\hline $\begin{array}{l}\text { Other Foreign } \\
\text { Citizens }\end{array}$ & 164.582 & 0.8 \\
\hline
\end{tabular}

Source: Based on Tables 2.10 and 2.11, Department of Statistics, Malaysia (2005) 
will belong to different groups (Rae and Taylor 1970: 22-23). Table 8.2 below shows the values of the EFI for selected countries. Although the EFI is affected by the way the ethnic groups are measured for each country, it nevertheless can be used to provide a broad indication of the degree of diversity. The index for Malaysia is not as high as say, India, about the same as Canada and much greater than, say, the UK.

One reason for great variety of ethnic, religious and linguistic groups in Malaysia can be traced to its geographical location. The region that is now Malaysia comprises Peninsular Malaysia, a peninsula jutting out from the Asian continent and East Malaysia, comprising Sabah and Sarawak, two regions in the island of Borneo. Peninsular Malaysia lies at the crossroads of maritime trade between the West (India and Arabia) and the East (China). The seas between North Borneo (now Sabah) and the Sulu islands have been an important trading route between Australia and China. There have thus been far-reaching movements of peoples between the West and the East and within Southeast Asia itself (Andaya and Andaya 1982).

The richness of the ethnic heritage can be seen in the census categories used for ethnicity in the census in 1891 of the then Straits Settlements (comprising Penang, Singapore and Malacca) shown in the first column of Table 8.3. The list indicates that the Straits Settlements were home at least for some length of time to many different groups. These groupings indicate that there were people from different continents (Europeans and Americans), religions ('Parsees' and 'Hindoos') and from neighbouring regions ('Javanese' and 'Manilamen'). However, these categories were, as Hirschman (1987) observes, made up based on 'experience and common knowledge' and not necessarily on size of group in the society. Indeed, as Table 8.4 shows, the large number of categories for 'Europeans and Americans' was in direct contrast to their small proportion in the population of the time.

The inflow of immigrant workers from certain countries in somewhat large numbers also helped to define the ethnic fabric of the country. The turn of the nineteenth

Table 8.2 Ethnic

fractionalization index (EFI), selected countries

\begin{tabular}{l|l}
\hline Country & EFI \\
\hline Republic of India & 0.876 \\
\hline Republic of the Philippines & 0.838 \\
\hline Republic of Indonesia & 0.754 \\
\hline Canada & 0.714 \\
\hline Malaysia & 0.694 \\
\hline Kingdom of Thailand & 0.535 \\
\hline United States of America & 0.395 \\
\hline United Kingdom of Great Britain \& & 0.325 \\
N. Ireland & \\
\hline Solomon Islands & 0.133 \\
\hline
\end{tabular}

Source: Based on Table 1, Yeoh (2001) 
Table 8.3 Ethnic classifications, selected censuses and regions

\begin{tabular}{|c|c|c|c|}
\hline 1871 & 1957 & 1960 & 1960 \\
\hline Straits Settlements & Federation of Malaya & North Borneo & Sarawak \\
\hline $\begin{array}{l}\text { Europeans and } \\
\text { Americans (18 } \\
\text { sub-categories) }\end{array}$ & Malaysians & $\begin{array}{l}\text { European ( } 2 \\
\text { sub-categories) }\end{array}$ & $\begin{array}{l}\text { European }(2 \\
\text { sub-categories) }\end{array}$ \\
\hline Armenians & Malays & Dusun & Malay \\
\hline Jews & Indonesian & Murut & Melanau \\
\hline Eurasians & All Aborigines & $\begin{array}{l}\text { Bajau ( } 2 \\
\text { sub-categories) }\end{array}$ & Sea Dayak \\
\hline Abyssinians & Negrito & Brunei & Land Dayak \\
\hline Achinese & Semai & Kedayan & Other Indigenous \\
\hline Africans & Semelai & Orang Sungei & Bisayah \\
\hline Andamanese & Temiar & Bisaya & Okedayan \\
\hline Arabs & Jakun & Sulu & Kayan \\
\hline $\begin{array}{l}\text { Bengalees and Other } \\
\text { Natives of India not } \\
\text { particularized }\end{array}$ & Other Aborigines & Tidong & Kenyah \\
\hline Boyanese & Chinese & Sino-Native & Kelabit \\
\hline Bugis & Hokkien & Chinese & Murut \\
\hline Burmese & Tiechiu & Hakka & Punan \\
\hline Chinese & Khek (Hakka) & Hokkien & Other Indigenous \\
\hline Cochin-Chinese & Cantonese & Teochew & Chinese \\
\hline Dyaks & Hainanese & Hailam (Hainanese) & Cantonese \\
\hline Hindoos & Hokchia & Other Chinese & Foochow \\
\hline Japanese & Hokchiu & Others & Hakka \\
\hline Javanese & Kwongsai & Natives of Sarawak & Henghua \\
\hline Jaweepekans & Henghwa & Malay & Hokkien \\
\hline Klings & Other Chinese & Cocos Islander & Hylam/ Hainese \\
\hline Malays & Indians & Indonesian & Teochew \\
\hline Manilamen & Indian Tamil & $\begin{array}{l}\text { Indian, Pakistani, } \\
\text { Ceylonese }\end{array}$ & Other Chinese \\
\hline Mantras & Telegu & Native of Philippines & Others \\
\hline Parsees & Malayali & Others & $\begin{array}{l}\text { Indian, Pakistani, } \\
\text { Ceylonese }\end{array}$ \\
\hline Persians & Other Indian & & Indonesian \\
\hline Siamese & Others & & Others \\
\hline \multirow[t]{9}{*}{ Singhalese } & Eurasian & & \\
\hline & Ceylon Tamil & & \\
\hline & Other Ceylonese & & \\
\hline & Pakistani & & \\
\hline & Thai (Siamese) & & \\
\hline & Other Asian & & \\
\hline & British & & \\
\hline & Other European & & \\
\hline & $\begin{array}{l}\text { Others (not } \\
\text { European or Asian) }\end{array}$ & & \\
\hline
\end{tabular}

Source: First two columns, Hirschman (1987); last two columns, Jones (1961); Jones (1962) 
Table 8.4 Proportion of population by nationality, Straits Settlements, 1881 and 1891

\begin{tabular}{l|l|l}
\hline Nationality & 1881 & 1891 \\
\hline Europeans and Americans & 0.0082 & 0.0129 \\
\hline Eurasians & 0.0163 & 0.0138 \\
\hline Chinese & 0.4118 & 0.4450 \\
\hline Malays and other natives of the archipelago & 0.4503 & 0.4159 \\
\hline Tamils and other natives & 0.0975 & 0.1052 \\
\hline Other nationalities & 0.0069 & 0.0072 \\
\hline Total population & 423,384 & 512,905 \\
\hline
\end{tabular}

Source: Merewether (1892)

century in British Malaya saw the successful policy of bringing in migrant labour to work on rubber estates (workers from India) and tin mines (workers from China), when these primary products grew in economic importance. The increase in the relative size of these two groups could be seen as early as 1891 (Table 8.4). The British also tried to encourage immigration into North Borneo in the early part of the twentieth century to work in the estates there.

Since the 1970s, Malaysia has seen an increasing presence of migrant workers as the need for estate workers, and more recently, factory workers, maids, restaurant workers and security guards has increased. These have been mostly from Indonesia, and but also from Nepal, Bangladesh and the Philippines. Different from earlier British policy, these migrants are required to return home after a fixed period. However, economic opportunities have also made Malaysia a magnet for illegal economic migrants from neighbouring countries. Since Peninsular Malaysia shares a border with Thailand and is just across the Straits of Malacca from Indonesian Sumatra, while Sabah and Sarawak share a border with Indonesian Kalimantan, the erection of political boundaries even with Peninsular Malaysia's Independence from the British (1957) or the formation of Malaysia (comprising Peninsular Malaysia, Sabah (previously North Borneo) and Sarawak) has not been effective in reducing the diversity in the population. Thus, there continues to be considerable movement of people across Borneo, Indonesia and the Philippines.

These historical patterns have led to differences in ethnic composition - as well as ethnic categories measured - in Peninsular Malaysia, Sabah and Sarawak. The first region is concerned with three main ethnic groups, Malays, Chinese and Indians, that is, historically non-migrant versus historically migrant classifications, whereas Sabah and Sarawak are concerned with the historically migrant as well as the many indigenous groups in their society. This can be observed in the census categories for ethnicity for 1957 (Federation of Malaya) and North Borneo and Sarawak (1960) shown in Table 8.3. 


\subsection{The Measurement of Ethnicity in the Census}

The United Nations Statistics Division (2003) in reviewing the measurement of ethnicity in censuses contends that 'ethnic data is useful for the elaboration of policies to improve access to employment, education and training, social security and health, transportation and communications, etc. It is important for taking measures to preserving the identity and survival of distinct ethnic groups.' Yet, 1 in 3 of the 147 countries surveyed which had done a census in year 2000 had not included a question on national and/ or ethnic group (United Nations Statistics Division 2003: Table 3). While these countries may have included such a question in previous, or plan to include one in future, surveys, clearly it is not a question that regularly appears in their censuses.

In contrast, Malaysia's experience in measuring national/ race/ ethnic group in a regular decennial census can be traced back to the late 1800s. Regular censuses, other than during war years, have been carried out despite the difficulties of taking a census in a population 'with so many races speaking different tongues' (Hare 1902: 4) or the need to have census questionnaires prepared in several languages as well as enumerators who can speak the language of the respondents. Furthermore, in the timing of release of census information, ethnicity data has always been considered a priority (Chander 1972: 22) and may even be released along with other essential demographic data well before the general report on the census (compare for example, Department of Statistics, Malaysia (2001a) with Department of Statistics, Malaysia (2005)).

Hirschman (1987) has explored the meaning and measurement of ethnicity in Malaysia in his analysis of the census classifications until 1980. He notes that the first modern census was carried out in 1871 for the Straits Settlements (Penang, Malacca and Singapore) which were parts of what is now Peninsular Malaysia then under British rule. In 1891, separate censuses were conducted for the Straits Settlements and for each of the four states known as the Federated Malay States that were under British protection. The 1901 and 1911 censuses were unified censuses covering these two areas. In 1911, the taking of a census was extended to some of the Unfederated Malay States. In 1921 a unified census was conducted in the Straits Settlements, Federated Malay States and the Unfederated Malay States. This practice continued for the 1931 and 1947 censuses. The 1957 census, the year of Independence from the British, excluded Singapore (which by then was a Crown Colony). North Borneo (now Sabah) and Sarawak became British protectorates in 1888. North Borneo conducted its first census in 1891; and then in 1901, 1911, 1921, 1931; and then in 1951 and 1960. The first census for Sarawak was done carried out in 1947, and then in 1960. In 1963, Malaysia was formed comprising Peninsular Malaysia, Singapore, ${ }^{2}$ Sabah and Sarawak. From 1970, the decennial censuses have covered this geographical area. While these regions were all separate politically until 1963, they each had some form of linkage to the British. Thus it is

\footnotetext{
${ }^{2}$ Singapore seceded in 1965 to form its own nation.
} 
perhaps not surprising that a reading of the various census reports indicate experiences from censuses were shared.

Appendix 8.1 contrasts two related aspects of the various censuses, the measurement of ethnicity and number of categories. The measurement of ethnicity in the early years used the term 'nationality'. There were obviously difficulties in using this term ${ }^{3}$ to capture the various groups in the population, and E. M. Merewether, the Superintendent of the 1891 Census, in acknowledging the objections raised, proposed the word 'race' be used in subsequent censuses (Merewether 1892: 8). G. T Hare, the Superintendent of the 1901 Census of the Federated Malay States preferred the word 'race' as it is 'a wider and more exhaustive expression than 'nationality' and gives rise to no such ambiguous question in classifying people' (as cited in Hirschman 1987: 561). By 1911 the term had been changed to 'race' for the Straits Settlements as well, but 'nationality' continued to be used in North Borneo up till the 1931 census. L. W Jones, the Superintendent of the 1951 Census of North Borneo reported that the term 'nationality' was dropped as 'enumerators could not distinguish between nationality and race.' This issue did not arise in Sarawak as the first census in 1947 itself used the term 'race'. There was recognition (Noakes 1948: 29) of the many indigenous groups that regarded 'Sarawak as their homeland' and who were 'regarded as natives by their fellowmen.'

Although enumerators were told to use the term 'race' as 'understood by the man in the street and not physical features as used by ethnologists' (Fell 1960: 12), there was still dissatisfaction with the measurement. The 1947 census for Malaya and the 1970 census for Malaysia used the term 'community'. Chander (1972: 22) justifies the return to the practice of earlier Malayan censuses noting that 'the term race has not been used as it attempts to cover a complex set of ideas which in a strict and scientific sense represent only a small element of what the Census taker is attempting to define.' The term 'community' was used to identify a group 'bound by a common language/ dialect, religion and customs.'

There were further refinements and from the 1980 census, the term 'ethnic/dialectic/community group' has been used, although its description is the same as that used for 'community' (Khoo 1983: 289). Although the word 'dialect' was introduced formally only in 1980, enumerators have long been instructed to note the dialect when enumerating the Chinese community. Hare (1902: 6) recommended that in the next census that language be added in a separate column as 'if a person now writes "Chinese" it is hard to say to which race of Chinese he belongs.'

The second aspect of the measurement of ethnicity relate to the categories. The discussion here focuses on what has been presented or published, although it is possible that enumerators obtained more detail that was subsequently coded. Figure 8.1 shows a summary of the number of categories used in the various censuses. The column for Malaysia includes the information for the Federated Malay States and British Malaya since Hirschman (1987) finds that the unified census from 1921

\footnotetext{
${ }^{3}$ The term 'nationality' can be used to refer to a group with a common heritage, or established, among others, by place of birth, bloodline, place of residence or citizenship. http://www.answers. com/nationality\&r=67 [Accessed 1 October, 2007].
} 


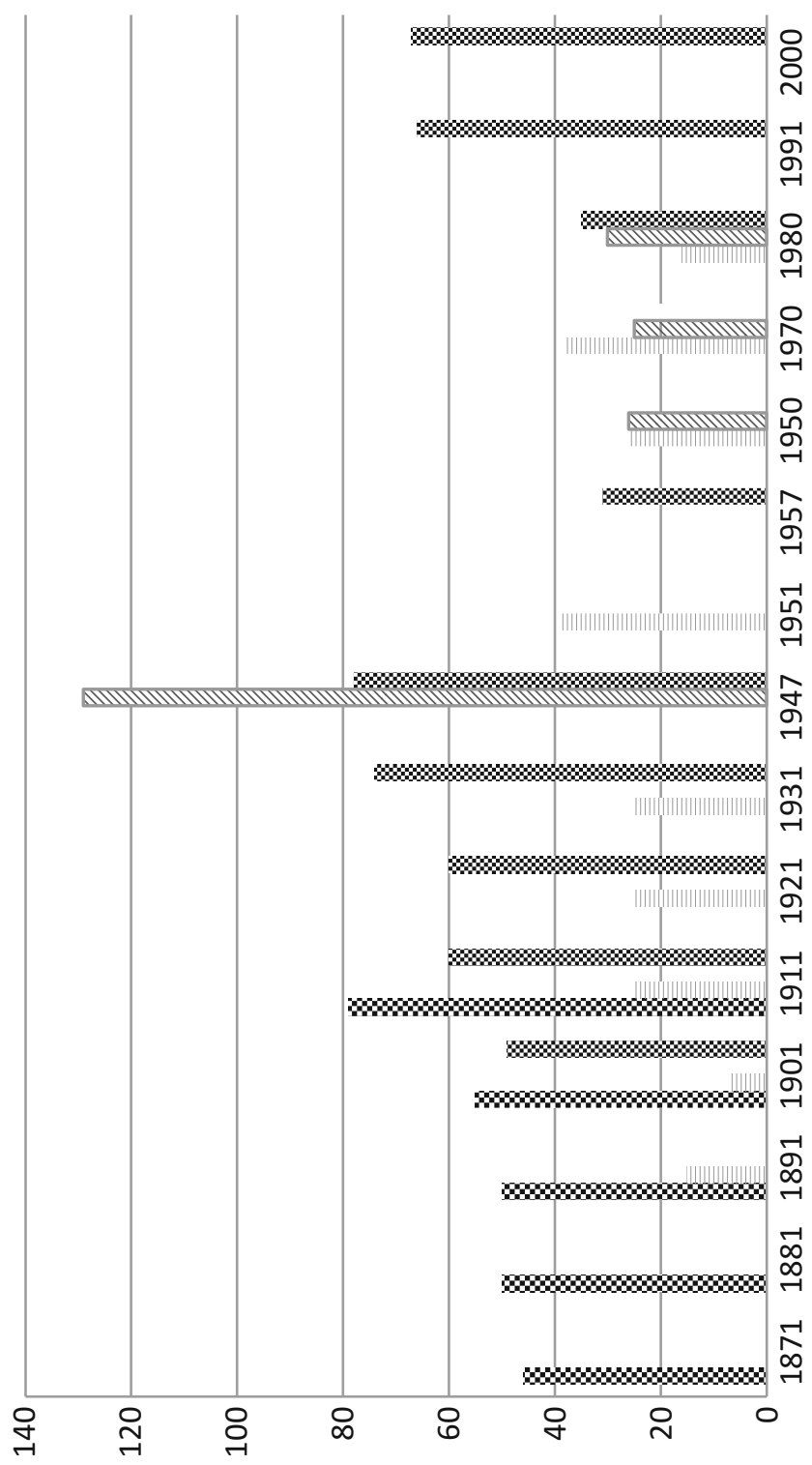

藏

哥

的施

○े

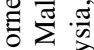

宊

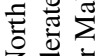

乙 효

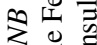

s.

, of

¿ี

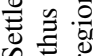

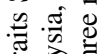

空全

放

的㐘

$\times$ :

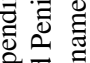

运焉

ธี

귱유

ص $\frac{1}{2}$

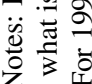

$\dot{0} \frac{0}{0}$

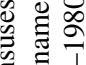

ज

过告

응

응

击

인

当. 흠

0 .

先

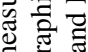

ह

\& 0

오요

论 吾

แั

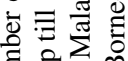

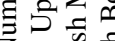

乙 $1: 0$

- $\frac{\pi}{5}$ 它

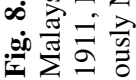


adopted basically the pattern for the Federated Malay States. A steady increase is observed in the early years of the censuses for the Straits Settlements, presumably reflecting the recognition of the different groups in the society. A similar pattern is observed for the Federated Malay States, and then British Malaya. The categories reduce for the early years of the Federation of Malaya. In contrast, Sarawak began in 1947 with 129 categories, reflecting the attempt - with the aid of Tom Harrison, Curator of the Sarawak Museum and Government Ethnologist - to document the many indigenous groups in its society, and then reduced the number when group size was ascertained. North Borneo did not have as many categories, showing an increase only in the 1951 census.

A major criterion for the inclusion of a group as a category would be its size in the population. Tom Harrison, in assisting in determining the categories for the Census, observes that (Noakes 1948: 271), "classification should be as scientifically accurate as possible, the groups must be reasonably balanced in size, and it should be in sufficient detail to provide a sound basis for future scientific investigations.' For example, the aborigines of Peninsular Malaysia are not a homogenous group ${ }^{4}$ (Nicholas 2004). Some of these are very small, like the 18 tribes of indigenous Proto Malays (estimated to number 147,412 in 2003) the smallest of these 18 tribes being an estimated 87 Kanaq people in $2007 .{ }^{5}$

One of the greatest problems has been the identification of people native to the region. Harrison (in Noakes 1948: 271) observes that 'certain cultural groups have become obscured and many complicating migrations have occurred.....all this is inevitable, and largely it should be... [but] .in planning a Census it introduces certain complications... [since] the exact definitions of groups must partly depend on their past.' The use of a definition like 'living naturally in a country, not immigrant or imported, native' requires determination of origin. For example, the enumeration of indigenous groups in Sarawak is problematic as many of these groups 'know themselves by the name of a place or river or mountain or even a local chief' (Harrison in Noakes 1948: 272).

Further, there can be confusion when religion comes into play, particularly in respect of who is a Malay. As Table 8.2 shows, the populace has included not just Malays but also many different groups that today would be regarded as originating from Indonesia. Among the terms used to refer to this group have been 'Malays and natives of the archipelago' and 'Malaysians'. In the 1956 census, Boyanese and Javanese were coded as Malays. Fell (1960: 12) observes that counting such groups can be difficult. Saw (1968: 10) comments that with the formation of Malaysia and the use of Malaysian to refer to a citizen of this nation, 'The best solution is to use the term 'Malays' to include Indonesians as well.' He argues that this is justified as most immigrants from the Indonesian Archipelago now have been absorbed into the

\footnotetext{
${ }^{4}$ Colin Nicholas, The Orang Asli of Peninsular Malaysia: A Brief Introduction. http://www.coac. org.my/codenavia/portals/coacv1/code/main/main_art.php?parentID=11497609537883\&ar $\mathrm{tID}=11509699100857$. [Accessed October 1, 2007].

${ }^{5}$ http://damak.jheoa.gov.my/intranet/index.php?mid=1\&vid=2. http://thestar.com.my/news/story. asp?file $=/ 2007 / 4 / 16 /$ southneast $/ 17200389 \&$ sec $=$ southneast. [Accessed October 1, 2007].
} 
community. The issue also extends to indigenous groups. As Noakes (1948) highlights, there has 'always been difficulty in measuring the size of the Melanau population as Islamic Melanaus frequently refer to themselves as Malays.'

The importance of a group especially for public policy would be a second criterion for their inclusion as a category. Jones (1961) observes that the category 'Cocos Islanders' was included because this group was introduced into the population, and so their progress would be of interest. The most dramatic example of the impact of public policy on census classification arises from the affirmative policy introduced by the NEP (1971) which provides for special benefits to Malays and indigenous groups. The term Bumiputera ('son of the soil') is used to refer to all those eligible for special benefits. The definition of ethnic groups eligible for these benefits is provided for in the Federal Constitution (see Appendix 8.2). These include Malays, Aborigines of Peninsular Malaysia and indigenous tribes of East Malaysia, the latter two groups sometimes referred to as pribumi or 'natives of the land'.

Some of these groups have been measured in the 1970 and 1980 census for Malaysia, but it was clear that the categories needed to be re-examined, and in particular, to identify and enumerate clearly the Bumiputera population. Furthermore, with growing interest in the increasing presence of foreigners, there was also the need to clarify groups in the population who could be separately identified by nationality, say Indonesian Malaysians versus Indonesian Indonesians. In 1991, there was a major rationalization of ethnic categories and presentation of ethnicity information since then has included information on citizenship.

The census classifications for the 2000 census (which are only slightly different from the 1990 classifications) are shown in Table 8.5. It is interesting to note that the detailed listing of groups in East Malaysia now resembles more the detailed classifications in the pre-Malaysia censuses of North Borneo and Sarawak. The greater diversity in the Sabah and Sarawak, which together have only about $20 \%$ of Malaysia's population, has been captured as can be seen from Table 8.6, which shows the regional EFI computed for ethnic and religious groups measured in the 2000 census. $^{6}$

The role of politics in determining census classifications cannot be discounted. When Datuk Harris Salleh won the elections in Sabah in 1981, he wanted to foster more rapid integration with Peninsular Malaysia and allowed only for the measurement of three categories (Bumiputera, Chinese and Others) in the 1980 census (Andaya and Andaya 1982: 297). With a change in his political fortunes, the 1991 census reverted back to the measurement and presentation of information on the indigenous groups in Sabah.

Politics has also influenced the categorization of the Kadazan-Dusun group in Sabah. The Dusun and Kadazan share the same language (albeit different dialects) and culture. Traditionally the Kadazan have resided in the valleys, and the Dusun in the hills. In 1989, with the formation of the Kadazan-Dusun Cultural Association,

\footnotetext{
${ }^{6}$ This also highlights the measurement issue in measuring ethnic diversity using the EFI. If a population is diverse but the groups are not measured then the index will show more homogeneity than it should.
} 
Table 8.5 Ethnic classification, 2000 census, Malaysia

\begin{tabular}{|c|c|c|}
\hline \multicolumn{2}{|l|}{ Malaysian citizens } & \multirow{2}{*}{$\begin{array}{l}\text { Non-Malaysian citizens } \\
\text { Singapore }\end{array}$} \\
\hline Bumiputera & Chinese & \\
\hline Malays & Hokkien & Indonesia \\
\hline Other Bumiputera & Khek (Hakka) & Philippines \\
\hline Negrito & Cantinese & Brunei Darussalam \\
\hline Senoi & Teochew & India \\
\hline Proto Malay & Hainanese & Bangladesh \\
\hline Dusun & Kwongsai & Other foreign countries \\
\hline Kadazan & Foochow/ Hokchiu & Unknown \\
\hline Kwijau & Henghua & \\
\hline Bajau & Hokchia & \\
\hline Iranun & Other Chinese & \\
\hline Murut (Sabah) & Indians & \\
\hline Rang Sungei & Indian Tamil & \\
\hline Sulu/ Suluk & Malayali & \\
\hline Bisaya (Sabah/ Sarawak) & Sikh/ Punjabi & \\
\hline Rungus & Telegu & \\
\hline Sino-native & Sri Lankan Tamil & \\
\hline Kadayan (Sabah/ Sarawak) & Singalese & \\
\hline Tidong & Bangladeshi & \\
\hline Tambanuo & Pakistani & \\
\hline Idahan & Other Indian & \\
\hline Dumpas & Others & \\
\hline Mangkaak & Indonesian & \\
\hline Minokok & Thai & \\
\hline Maragang & Filipino & \\
\hline Paitan & Myanmar & \\
\hline Rumanau & Japanese & \\
\hline Lotud & Korean & \\
\hline Cocos Islander & Other Asian & \\
\hline Other Bumiputera (Sabah) & Eurasian & \\
\hline Iban/ Dayak Laut & European & \\
\hline Bidayuh/ Dayak Darat & Others & \\
\hline Melanau & & \\
\hline Kenyah & & \\
\hline Lun Bawang/ Murut (Sarawak) & & \\
\hline Penan & & \\
\hline Kajang & & \\
\hline Kelabit & & \\
\hline Other Bumiputera (Sabah) & & \\
\hline
\end{tabular}

Source: Department of Statistics, Malaysia (2001a) 
Table 8.6 Ethnic fractionalization index, Malaysia, 2000

\begin{tabular}{l|l|l}
\hline Region & EFI & $\begin{array}{l}\text { Percentage of total } \\
\text { population }\end{array}$ \\
\hline Sabah & 0.889 & 11.2 \\
\hline Sarawak & 0.874 & 8.9 \\
\hline Peninsular Malaysia & 0.655 & 79.9 \\
\hline All Malaysia & 0.701 & 100 \\
\hline
\end{tabular}

Computed from data in Tables 4.1, 4.11 and 4.12, Department of Statistics, Malaysia (2001a) only for religious and ethnic groups

the term Kadazan-Dusun was coined. Up to the 1960 census of North Borneo, only the category 'Dusun' was used. For the 1970 and 1980 census, the category 'Kadazan' was used. Since the 1991 census, both categories have been used, although in the presentation of information, both categories are combined as 'Kadazan-Dusun'.

One important issue is how ethnicity is measured in the censuses. This has always been by self-identification, and applies to the question on citizenship as well. Jones (1962: 44) articulates the reason clearly: 'An individual's answer to the question on race should be accepted without question, for there would be many persons descended from at least two of the tribes listed who would claim one as their own for their own private reasons and with whom it would be quite improper to discuss or dispute these reasons.' For persons of mixed parentage, the 1970 census, which used the definition of 'community', sought to identify the ethnic group to which the person felt he or she belonged (Chander 1977: 289) failing which father's community was used. ${ }^{7}$

The measurement by self-identification, the definition of Malay and the difficulty of separating race and religion suggest that there will be great difficulty in measuring certain groups of the population. Indeed, in explaining why the Chief Minister of Sabah said that half of the state's population is Malay, the Chief Minister of Malacca is reported to have said that 'it is easy to become a Malay... a person who is a Muslim, converses in Malay and follows the Malay traditions is considered a Malay'. ${ }^{8}$ A comparison of population figures by major ethnic categories for 1991 and 2000 suggests that indeed the identification of Bumiputera groups is problematic. The share of 'Malays' and 'Other Bumiputera' have risen greatly while the share of 'Other Malaysians' has declined.

The increase cannot possibly come from a greater fertility rate. For example, the implied average annual growth rate for Malays is $3.2 \%$ per year which is much greater than the average annual growth rate based on demographic data in 1998 of $2.6 \%$ (Department of Statistics, Malaysia 2001b: Table A1.4). The implementation of

\footnotetext{
${ }^{7}$ This would suggest a serious undercounting of mixed marriages if census data are used. While the extent of mixed marriages can be determined (see, for example, Tan 1986; Nagaraj 2009), it would not be possible to identify the ethnicity of offspring from such marriages.

${ }^{8}$ http://blog.limkitsiang.com/2007/06/11/it-is-easy-to-become-a-malay/. [Accessed October 1, 2007]. This is in line with the definition of Malay shown in Appendix 8.2. Andaya and Andaya (1982, p. 302) note that the definition of 'Malay' in the Constitution just formalized colonial practice. In fact the definition is that used by the British to define 'Malay reservation' land.
} 
the NEP in 1970s and 1980s witnessed mass exodus of Chinese accompanied by capital flight. Between 1970 and 1980 the Chinese had experienced a migration deficit of close to 200,000 persons and this accelerated to close to 400,000 in the following decade (Chan and Tey 2000). While the exodus of the Chinese had come to a halt in the 1990s, the slower rate of natural increase of the Chinese and Indians as compared to the Malays and other Bumiputera would result in further changes in the ethnic composition of the country. The Chinese and Indians in Malaysia have dipped below replacement level fertility by the turn of the twenty-first century, but the total fertility rate of the Malays remains well above replacement level, at about 3 per woman.

\subsection{Measurement of Ethnicity for Other Purposes}

The discussion has so far focused on the measurement of ethnicity in population censuses. Ethnicity data is also important is in the collection of information of other information on population. Registration of births and deaths, which is used to produce vital statistics data, comes under the purview of the National Registration Department. The identification of ethnicity on the Birth Certificate would be that entered by the person filling up the form. This would be the parent usually, but there may be circumstances where the information is entered by a third person (say, a policeman in the interior). Births and deaths data was up till the end of the 1990s coded by the Department of Statistics, Malaysia. This function has now been taken on by the National Registration Department. It is nevertheless likely that with the close cooperation between these two government departments the coding for ethnicity will be as detailed as provided for in the census. The Department of Statistics, Malaysia also has close ties with other government departments like the National Population and Family Development Board (NPFDB) [previously the National Family Planning Board]. Information on fertility, family planning and contraceptive use has been collected by the NPFDB since the late 1960s. The early surveys used the then Census term 'race' to capture ethnicity, but from the 1970s, the NPFDB adopted the term 'community' and then from 1989, the term 'ethnic group' has been used.

Ethnicity is also measured by many institutions, whether for targeting public policy in general or in line with the need to identify target groups and monitor their progress with regard to the NEP. As Appendix 8.3 shows, Article 153 in the Constitution specifies that special privileges may be provided in education, scholarships and training, employment in public service and business licenses. Besides that, the NEP aims to reduce the identification of race with occupation and to achieve increased Bumiputera participation in the economy. Thus, ethnicity information is collected by government, by banks, by licensing agencies and other institutions that need to maintain the necessary information for policy monitoring.

Since the size of some of the smaller ethnic groups in some sub-populations may be small, categories of ethnicity may be limited to the (perceived or otherwise) major groups in the sub-population. For example, ethnicity is captured both for 
Table 8.7 Economic census, manufacturing, 2006, ethnic classifications for employment

\begin{tabular}{l|l}
\hline Malaysians & Non-Malaysians \\
\hline Bumiputera & Indonesians \\
\cline { 1 - 1 } Malays & Filipinos \\
\hline Ibans & Bangladeshi \\
\hline Bidayuhs & Others \\
\hline Bajaus & \\
\cline { 1 - 1 } Kadazans & \\
\cline { 1 - 1 } Other Bumiputera & \\
\cline { 1 - 1 } Chinese & \\
\cline { 1 - 1 } Indians &
\end{tabular}

Source: http://www.statistics.gov.my/english/frameset_download.php?file=form [Accessed October 1, 2007]

ownership and employment in Economic Censuses conducted by the Department of Statistics, Malaysia. Table 8.7 shows the categories captured for employment. ${ }^{9}$ It is interesting to note that among the Bumiputera groups, 'Kadazan' has been captured but not 'Dusun'; that is, the original group name used in the pre-Malaysia censuses has been dropped altogether. Since these forms are filled by the firms, it is possible that some Dusun employees may have been categorized under 'Other Bumiputera'.

On the other hand, the number of pre-coded ethnic groups can be an issue especially when a database is expected to reach everyone in the population. For example, the ethnic categories initially used in the Educational Management Information System ${ }^{10}$ were based on the composition of the population in Peninsular Malaysia, and were thus too broad to identify the proportion of children from a specific indigenous group in school. These codes were subsequently expanded as needed. ${ }^{11}$ The more important classification for educational outcomes is that of Bumiputera. The monitoring of ethnic outcomes of entry into public tertiary institutions is based on parents' ethnicity and reads thus ${ }^{12}$ :

\footnotetext{
${ }^{9}$ Ownership has similar categories for the category 'Malaysians', but there is no distinction among Non-Malaysians.

${ }^{10}$ Education is essentially a federal matter with a common syllabi and examinations. The UNESCO website notes that the Educational Management Information System was 'originally designed to be a management tool but is gradually being perceived as an indispensable tool and support system for the formulation of education policies, their management, and their evaluation' (http://portal. unesco.org/education/en/ev.php-URL_ID $=10202 \&$ URL_DO=DO_TOPIC\&URL_ SECTION=201.html, Accessed October 10, 2007).

${ }^{11}$ Report on 'The Workshop on Optimizing the Use of Official Statistics for Socioeconomic Research and Planning', 22 November, 2006, Faculty of Economics and Administration, University of Malaya. Unpublished.

${ }^{12}$ Buku Panduan Kemasukan ke Institusi Pengajian Tinggi Awam, Program Pengajian Lepasan SPM/Setaraf Sesi Akademik 2007/2008. http://en.wikipedia.org/wiki/Bumiputra [Accessed October 1, 2007].
} 
Peninsular Malaysia: 'If one of the parent are Muslim Malay or Orang Asli as stated in Article 160 (2) Federal Constitution of Malaysia; thus the child is considered as a Bumiputra'

Sabah: 'If a father is a Muslim Malay or indigenous native of Sabah as stated in Article 160A (6)(a) Federal Constitution of Malaysia; thus his child is considered as a Bumiputra'

Sarawak: 'If both of the parent are indigenous native of Sarawak as stated in Article 160A (6)(b) Federal Constitution of Malaysia; thus their child is considered as a Bumiputra'

Other institutions also collect information on ethnicity. For example, Maybank, the largest bank in Malaysia with over 334 domestic branches all over the country and over 34 international branches, obtains from the applicant for a new account, information on 'race', coded in five categories: 'Malay', 'Native', 'Chinese', 'Indians' and 'Others' ${ }^{13}$ In other cases, it is unclear what coding is applied by the collecting institution. For example, the application form for the Practising Certificate, ${ }^{14}$ an annual requirement for a practicing lawyer, calls for the applicant to enter his or her 'ethnicity'. Yet other institutions use terms that are unclear. For example, the application for a contract post as a medical specialist with the Ministry of Health ${ }^{15}$ asks for 'nationality', which could be referring to ethnic group or citizenship. Nevertheless, the form for the annual practising certificate for doctors does not request information on ethnicity.

Ethnicity data are also obtained routinely as a part of administrative and monitoring procedures for areas that are not within the purview of the NEP. For example, the Ministry of Health $(\mathrm{MOH})$ provides information on the utilisation of public health care services (mainly referring to $\mathrm{MOH}$ services) by major ethnic groups, including indigenous groups, for Peninsular Malaysia and Sabah and Sarawak (see Table 8.8 below). The information on ethnicity is entered on admission/ attendance forms by admission clerks who commonly base their input on the patients' names and physical appearance, supplemented with verbal clarification only when in doubt. Patients in the Peninsular are usually classified as Malays, Chinese, Indians, Others or Non-citizens. Other indigenous groups, e.g., Senoi, tend to be recorded under 'Others'. In Sabah and Sarawak, because of heightened awareness of the diversity in the population, the clerk would generally obtain information on the actual aboriginal group. Thus, for these two states it is possible to generate data for smaller ethnic group breakdown if necessary.

Finally, it is of interest to note that there is official documentation of a person's ethnic group. The National Registration Department is responsible for the issuance of the MyKad (previously Identification Card) to all Malaysian citizens and permanent residents 12 years and above. Carrying an embedded microchip, it has at a minimum, the Identification Card number, name, ethnic group, date of birth,

\footnotetext{
${ }^{13}$ Online application form. https://www.maybank2u.com.my/maybank_group/application_forms/ banking/new_maybankacc.html. [Accessed 10 October, 2007].

${ }^{14} \mathrm{http}: / /$ www.malaysianbar.org.my/bardocs/membership/sijil_guaman.pdf. [Accessed October 1, 2007].

${ }^{15} \mathrm{http}: / /$ www.moh.gov.my/MohPortal/DownloadServlet?id=312\&type=1 [Accessed October 1, 2007].
} 
Table 8.8 Ethnic classifications for utilisation of public health care services, 2005

\begin{tabular}{l|l|l}
\hline Peninsular Malaysia & Sabah & Sarawak \\
\hline Malays & Malays & Malays \\
\hline Chinese & Bajaus & Melanaus \\
\hline Indians & Kadazans & Iban \\
\hline Peninsular indigenous & Murut & Bidayu \\
\hline Other Malaysians & Other Sabahan indigenous & Other Sarawak indigenous \\
\hline Non-citizens & Chinese & Chinese \\
\hline & Indians & Indians \\
\cline { 2 - 3 } & Other Malaysians & Other Malaysians \\
\cline { 2 - 3 } & Non-citizens & Non-citizens \\
\hline
\end{tabular}

Source: 2005 Annual report on medical sub-system, health management information system, information and documentation system, Ministry of Health, Malaysia

religion, photo and fingerprint and has to be carried by all persons when leaving home. ${ }^{16}$ Although this card could possibly be used to 'verify' ethnicity, particularly where special privileges are concerned, the information is only accessible via appropriate card-readers and its use limited by legislation.

\subsection{Concluding Remarks}

Malaysia has long been concerned with the measurement of its many ethnic groups, be it in the political, economic or social arena. The discussion above raises important questions on how ethnic groups have been defined, the purpose for which such data is gathered and how the data is gathered. The counting of its major and minor groups through self-identification has been an important function of the (usually) decennial census which aims to capture the diversity in the population. Information on ethnicity is also collected in almost all areas, whether in the public or private sector, where documentation related to the implementation of constitutional provisions on ethnicity is involved. In these non-census contexts, counting has been simple and local. The selection of categories may or may not have been well thought through being defined primarily to meet the local needs, and the data collected may or may not reflect self-identification of ethnicity depending on the manner in which the data is collected. Thus, data on ethnicity in Malaysia are important not just for social analysis and policy, as for example in New Zealand (Callister 2006; Callister et al. 2006), but also for economic and political analysis and policy. This is in sharp contrast to countries like France where even the potential use of official ethnic classification has seen strong debate (Morning 2008).

The study has highlighted the difficulties in collecting ethnic data and has shown how creative the data collection agencies have been over the years in defining and

\footnotetext{
${ }^{16}$ The information is based on the Birth Certificate. More recently, the Birth Certificate has been replaced by a chip embedded MyKid.
} 
redefining ethnicity as Malaysian society and needs evolve. While the identification of an ethnic group can be only as good as its measurement, Malaysia's experience with the measurement of ethnicity in censuses is underscored by the careful efforts by the various Superintendents of Census to define a diverse population. The first census in 1871 in the Straits Settlements may have used ethnic categories that were subjectively defined but each subsequent census has seen changes in line with size of group or its importance to public policy. There has also been considerable sharing of experiences across the three regions even under British rule or protection that has made possible the fairly detailed ethnic classification used in recent censuses, and which have shown the great diversity in the country, and more so across regions. The categorization of groups has also changed to accommodate changes in society. It is pertinent to note that categories have been refined, updated as required ${ }^{17}$ or revised as necessary. ${ }^{18}$ Since 1991, however, the measurement has been fairly detailed in respect of indigenous groups. Statisticians have also demonstrated their ability in collecting census data from people of 'many tongues', even against the odds of collecting data in the remotest parts of Sabah and Sarawak, doing so on a relatively regular interval. Ethnicity is also captured in other censuses and surveys, as well as in administrative databases. The population census categories have provided a guide; however, the degree of fineness of ethnic categories captured is based on purpose and need.

Over the years, the specific form of the question measuring ethnicity in the population census has been modified to capture ethnic/ dialect groups. The term used has changed from 'nationality' to 'race' to 'ethnicity/community/dialect'. Other surveys and censuses may use any of these terms. Across the world, population censuses have used a variety of terms: ethnicity, nationality, tribe, indigenous group, race (Morning 2008). The United Nations Statistics Division (2003) concludes that based on the current wording of the ethnicity question in the census, which includes dialect group in the definition, language is the principal criteria for measuring ethnicity in Malaysia. This study has shown that this is not entirely correct. The Malaysian experience with the population census reflects attempts to capture a conceptualization of an ethnic group as one that shares common interests such as language, religion and customs. Nevertheless, it cannot be denied that despite all these years of experience in counting, there can still be confusion about concepts such as race (e.g., Chinese), dialect group (e.g., Hokkien or Cantonese), language group (e.g., Tamil or Telegu), nationality (Indian vs. Sri Lankan) or even ethnicity itself.

The identification of ethnicity is based on self-identification in censuses, but in other cases may be entered by a third party. Irrespective of term used to capture ethnicity, Malaysians are generally used to providing information on their ethnicity even if different terms are used to capture this information. Since just one category is provided for, there is therefore no provision to capture those who belong to more than one ethnic

\footnotetext{
${ }^{17}$ This includes adjustment to new political entities or new names: India, Pakistan, 1947; Indonesia, 1949; Sri Lanka, 1948; Siam to Thailand by official proclamation, 1949, Brunei, 1984; Burma to Myanmar - 1989 .

${ }^{18}$ The category 'Kwijau' was dropped in 1960 census of North Borneo due to small numbers but was reintroduced in 1970 census for Malaysia.
} 
group, as for example, children of mixed marriages. A number of countries which capture information on ethnicity have moved to allowing respondents to check more than one category (for example, Canada, United States of America and New Zealand), allowing generic mixed ethnic group responses (for example, Anguilla, Guyana and Zimbabwe) or providing specific mixed ethnic group combinations (for example, United Kingdom, Cook Islands and Bermuda) (Morning 2008). Furthermore, ethnicity as measured in Malaysian censuses captures basically whatever the respondent answers to the question, that is, what he or she perceives ethnicity to be. Essentially, it measures identity, which as Statistics Canada (2006) notes, ${ }^{19}$ has 'a certain appeal because it attempts to measure how people perceive themselves rather than their ancestors.' Given that mixed marriages do occur in Malaysia, the extent of the rich diversity in Malaysian society can be better captured with allowing respondents to check more than one category. Hirschman (1993) suggests that two distinct aspects be captured, primary ethnicity (which is essentially what is already obtained currently in the census) and ancestry (which captures origins and an individual could have multiple ancestries). However such a move, would as Sawyer (1998) emphasizes, require that there are clear and meaningful, and we would add transparent, guidelines on how federal agencies should tabulate, publish, and use the data once it is collected.

This is particularly important since the need to monitor the NEP has focused attention on whether a citizen is a Bumiputera or not, where the definition of a Bumiputera is constitutionally defined. The somewhat loose constitutional definition has resulted in a growth of this group. Has this now entered the social realm so that we can consider the 'Bumiputera' community as an ethnic group? It would appear so, both in terms of Yinger's (1986) description discussed previously as well Statistics Canada's measurement of ethnicity, since the Bumiputera can be distinguished as a group which has a wide range of cultural, linguistic, religious and national characteristics. It also meets Sawyer (1998) three criteria for establishing an ethnic category for statistical purposes: consistency and comparability of data over time as well a category that is widely understood, so that meaningful comparisons can be made to evaluate social progress. There are also the seemingly easy shifts between 'Malays', 'Other Bumiputera' and 'Other Malaysians' which reflect in part the commonalities in origin of a considerable part of the populace from the neighbouring regions that are now politically different, that is, Indonesia, Philippines and Thailand. The movement of such peoples across the region in search of economic prosperity is not new, and continues to occur. Political boundaries that straddle cultural similarities continue to cause friction, as for example, the current row over whether Malaysia can use the popular ditty Rasa Sayang which some Indonesian legislators consider is part of Indonesia's heritage, in its Truly Asia campaign. ${ }^{20}$ One implication of the shifting groups between 'Malays', Other Bumiputera and 'Other Malaysians'

\footnotetext{
${ }^{19}$ Identity is as Statistics Canada (2003) notes, one of three ways of measuring ethnicity. The other two are "origin or ancestry and race. Origin or ancestry attempts to determine the roots or ethnic background of a person. Race is based primarily upon physical attributes fixed at birth among which skin colour is a dominant, but not the sole, attribute.' http://www.statcan.ca/english/concepts/definitions/ethnicity.htm. [Accessed October 1, 2007].

${ }^{20}$ Rasa Sayang 'ours too... we have right to sing it'. New Straits Times, October 15, 2007.
} 
categories suggests an underlying similarity, at the very minimum, recognition of the Bumiputera as a group both in the official and economic realms.

Although ethnic information - however imperfect - is collected and maintained by public producers of data, it is rarely available to the public, including researchers, as confidentiality is seen as a rein on ethnic sensitivities. ${ }^{21}$ The data collected on ethnicity permits analyses - often only by (or with the support of) the public sector since most data on ethnicity are officially classified as confidential - on outcomes of policies contrasting the achievements of the Bumiputera group usually against the Chinese and Indian groups, now increasingly a minority. Thus it is not surprising that there are starkly different analyses ${ }^{22}$ about the achievement of NEP targets. More than 30 years after the NEP, while there have been some improvements at least on the surface, inter-ethnic inequalities remain in educational achievement and occupational attainment, and in capital ownership as well as entrepreneurial spirit. The reality is that the Bumiputera are an increasingly heterogeneous group whose population is growing faster than that of the Non-Bumiputera, which may explain the observed decreasing variation among Chinese and increased variation among Malays in certain studies (see, for example, Nagaraj and Lee 2003). This raises questions on how ethnic data have been used and the policies that have been designed on the basis of the data gathered and examined (see, for example, Cheong et al. 2009).

The experience of Malaysia has also shown that not only does measurement of ethnic data support policy but that policy can also drive ethnic measurement in data. Should we then continue to collect ethnic data? The experience of census measurement of ethnicity in Malaysia lends credibility to Thomas Sawyer's assertion of the 'compelling human need for self-identity'. The nation, its Census Superintendents, its various institutions and its researchers have attempted to document the diversity in, and its effect on, society. So the answer is a resounding yes, we need to collect ethnic data, but do not just collect them. Perhaps it is time the focus shifts away from identifying major ethnic groups in order to design more effectively policies that reach the needy in the disadvantaged groups. Collect ethnicity data to meet the needs of sound policies that seek to build national unity, policies that utilize our diversity to our national advantage, that enable our citizens to celebrate the diversity. We can have unity in diversity and that is what nature itself teaches us. The problem is not the data themselves but how they are used to formulate, implement and monitor policies.

Open Access This chapter is distributed under the terms of the Creative Commons Attribution Noncommercial License, which permits any noncommercial use, distribution, and reproduction in any medium, provided the original author(s) and source are credited.

\footnotetext{
${ }^{21}$ There are exceptions. For example, detailed information on ethnic composition in a parliamentary constituency. Ethnicity is also an important factor in social science research, including public health. The issue of the relevance of ethnicity and its measurement in the medical field is addressed in several papers in PLoS Medicine, Vol 4(9), 2007. http://medicine.plosjournals.org/ perlserv/?request=get-toc $\& \mathrm{ct}=1$

${ }^{22} \mathrm{See}$, for example, the government-ASLI quarrel on the measurement of Bumiputera equity. http://www.malaysia-today.net/Blog-n/2006_10_05_MT_BI_archive.htm; http://www.malaysiatoday.net/Blog-n/2006/10/asli-backs-down-over-nep-data.htm.
} 


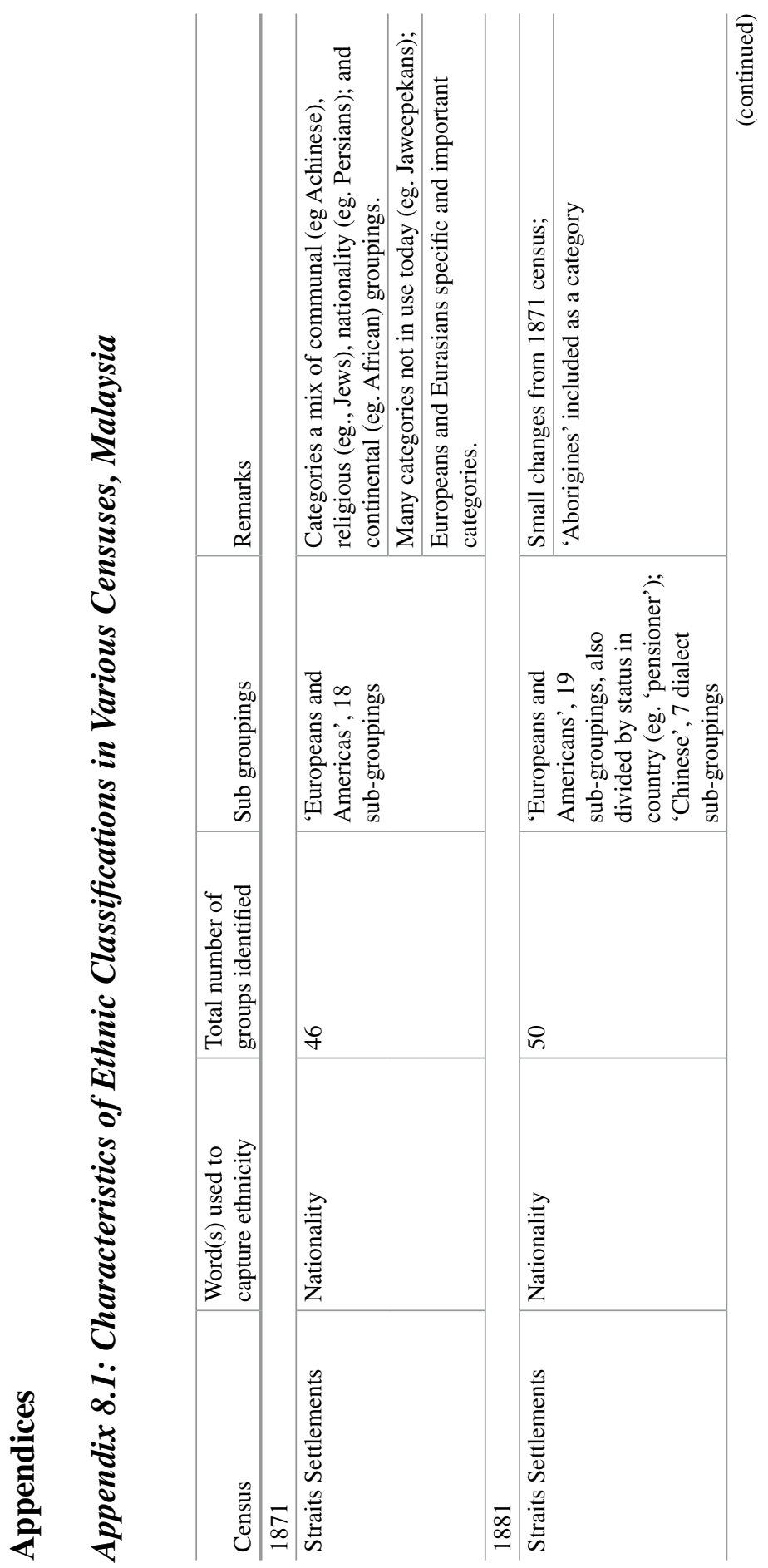




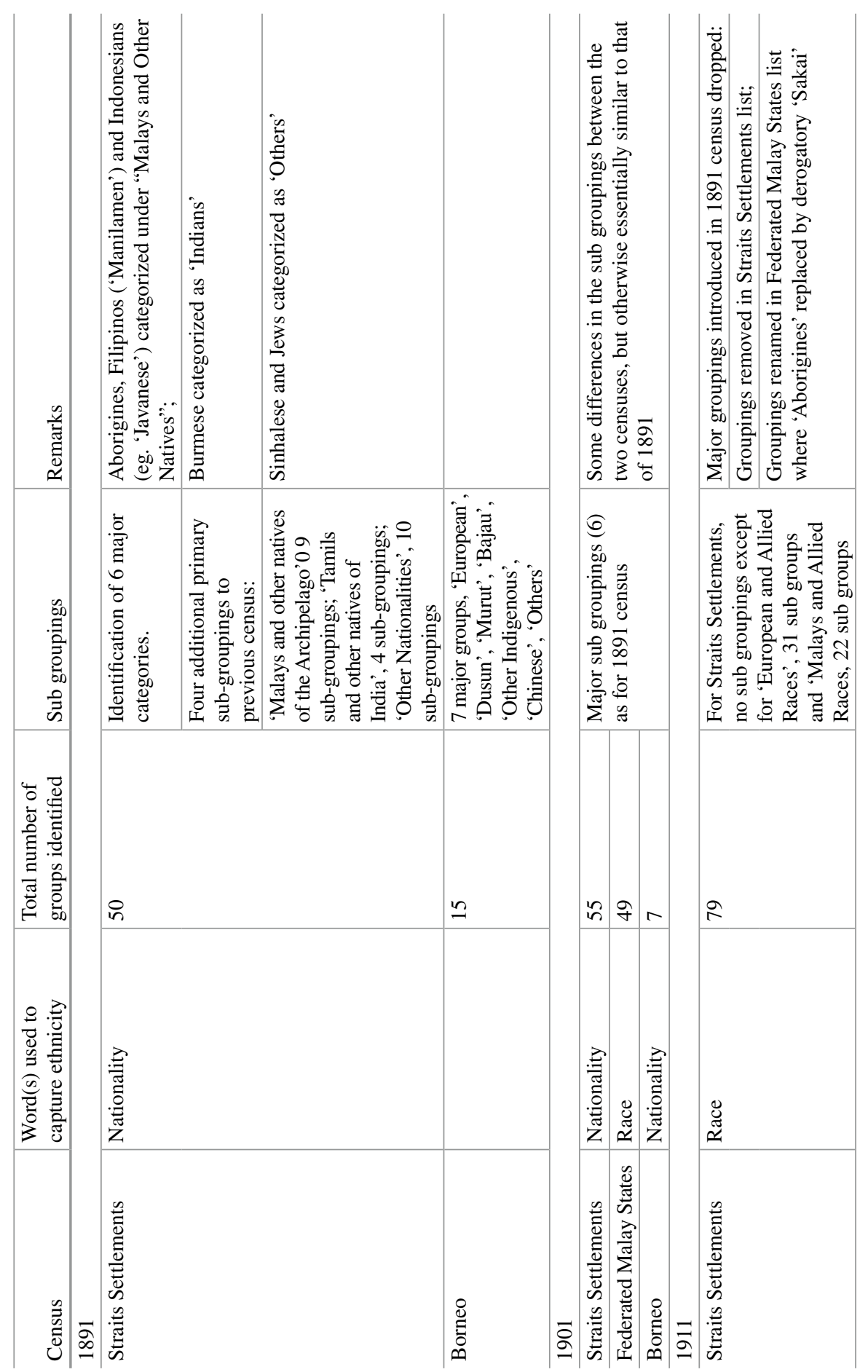




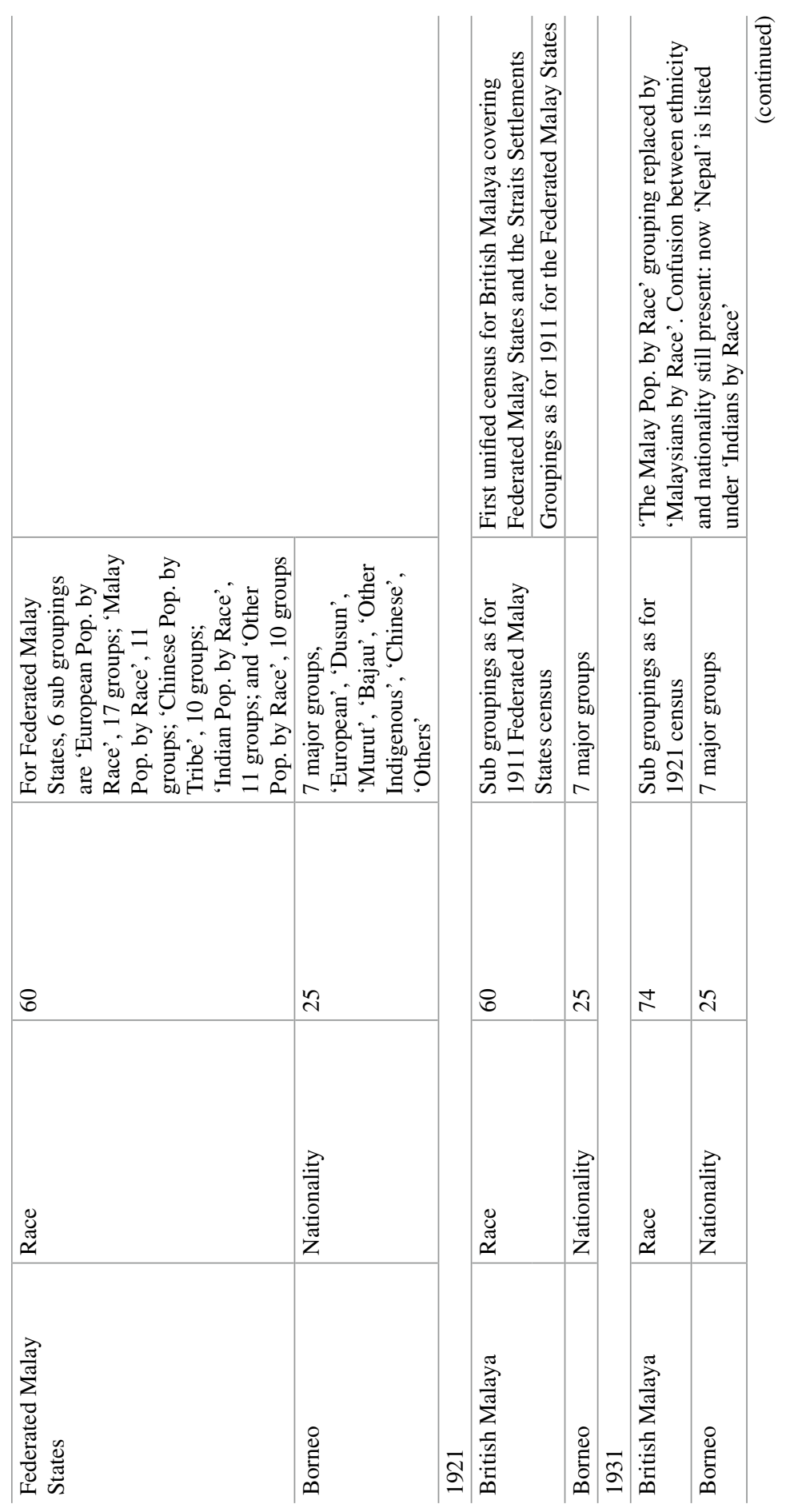




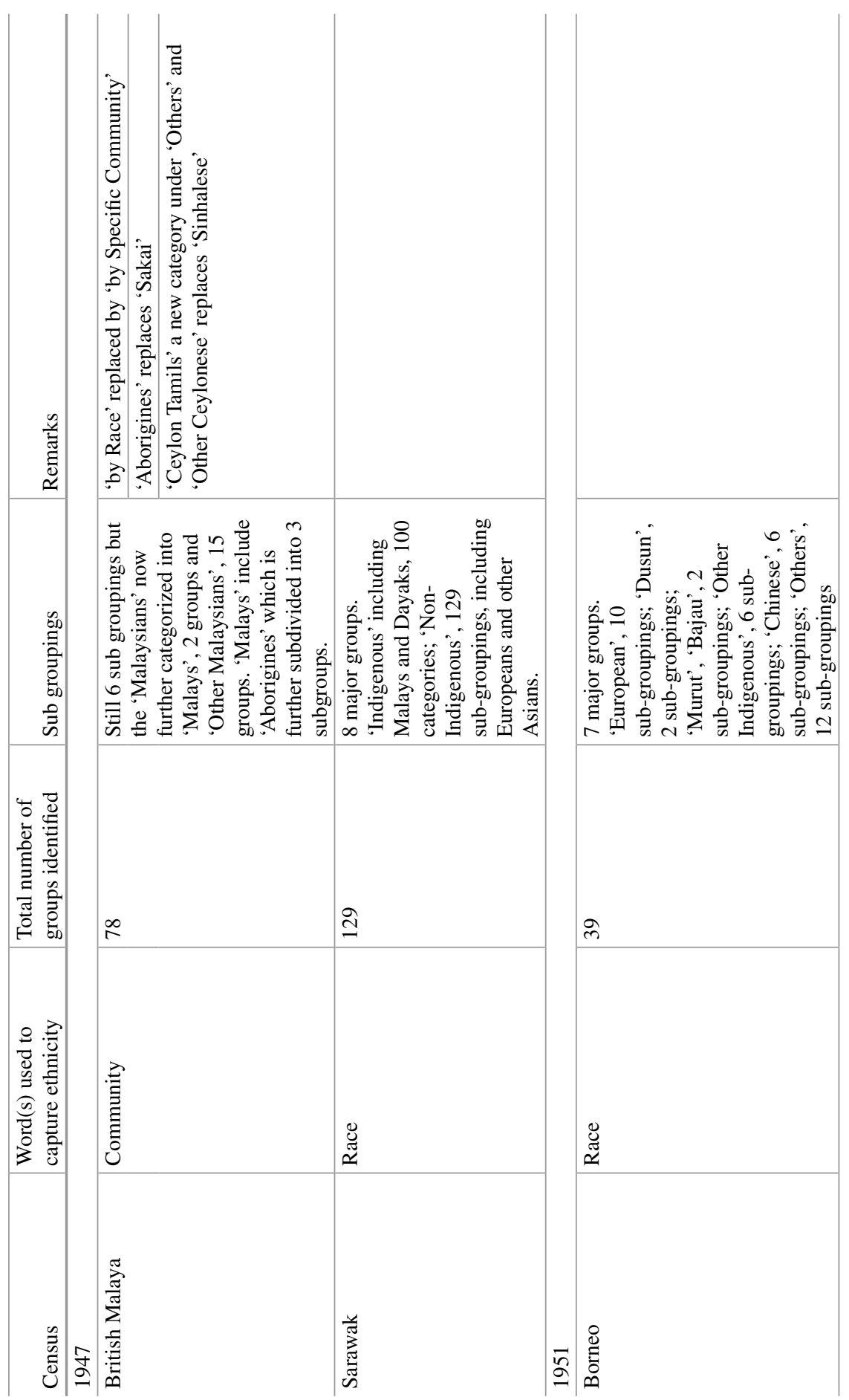




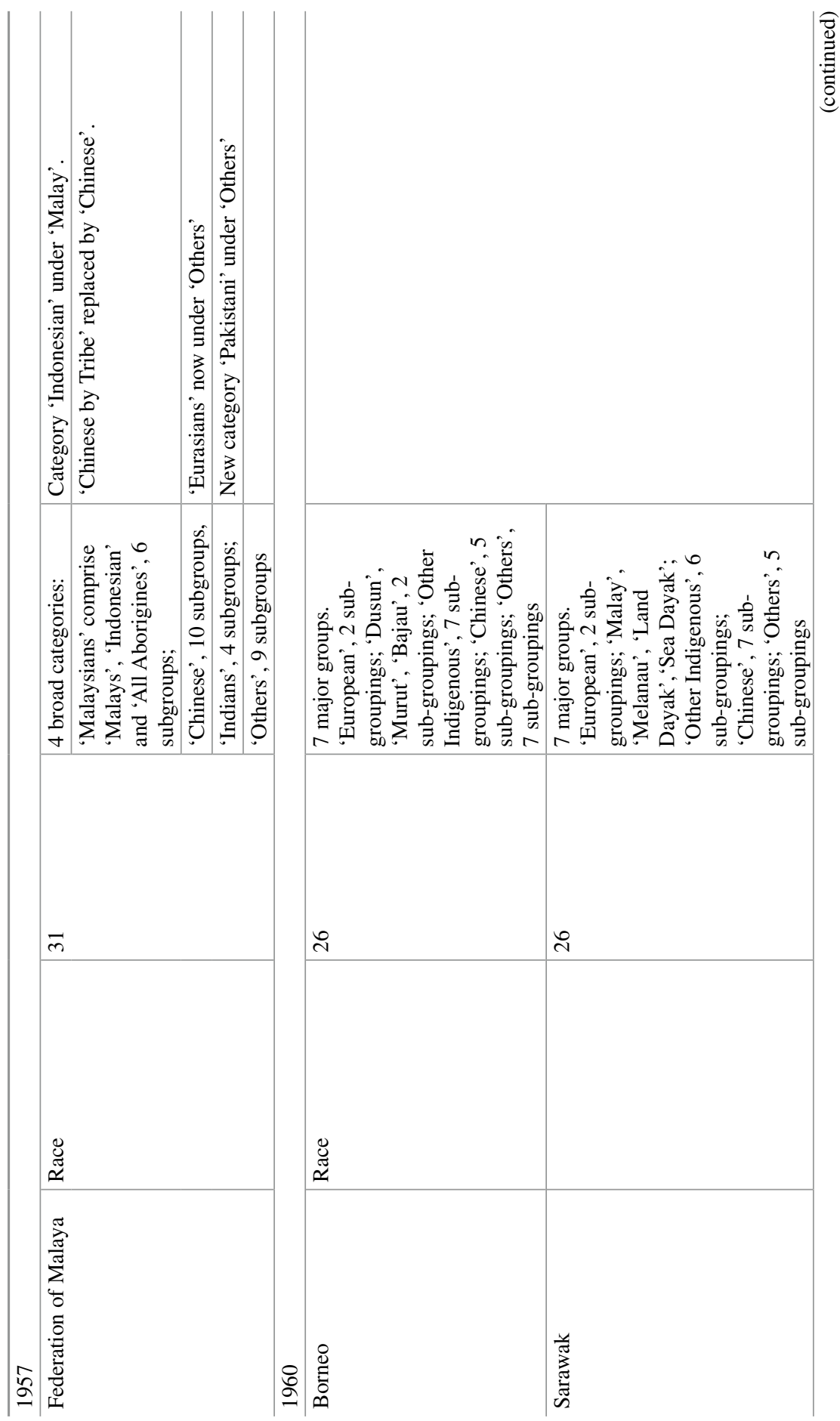




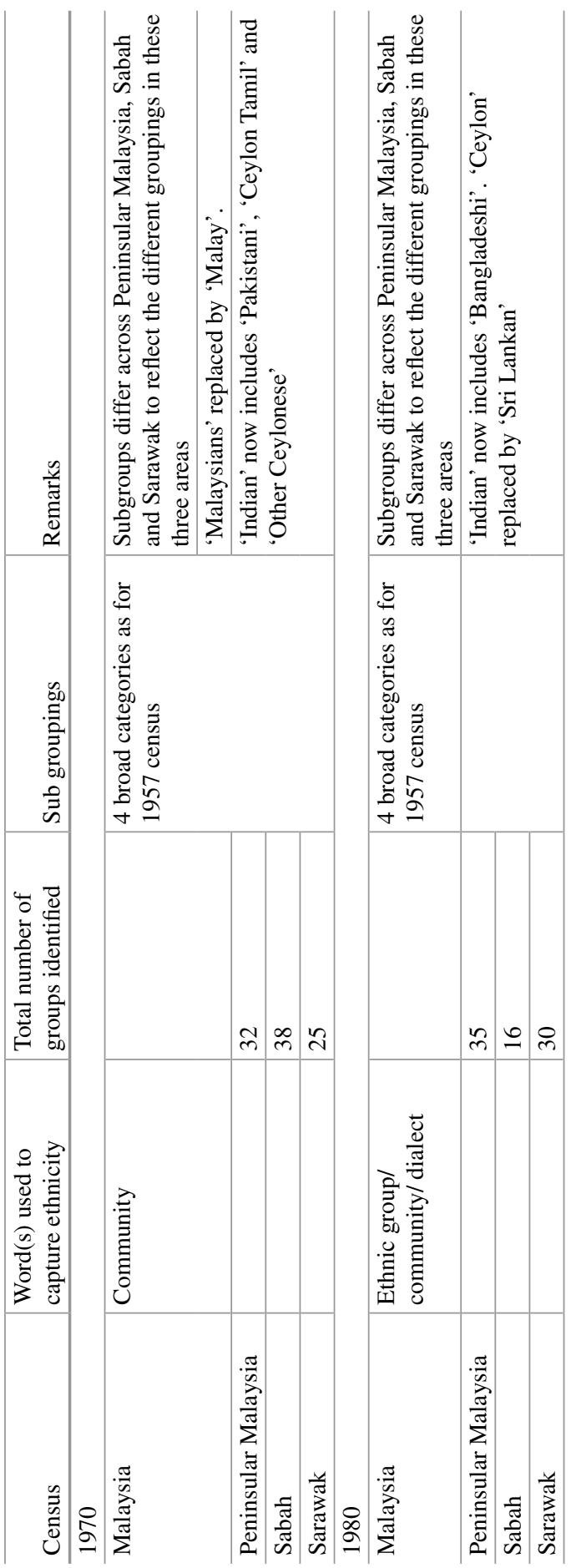




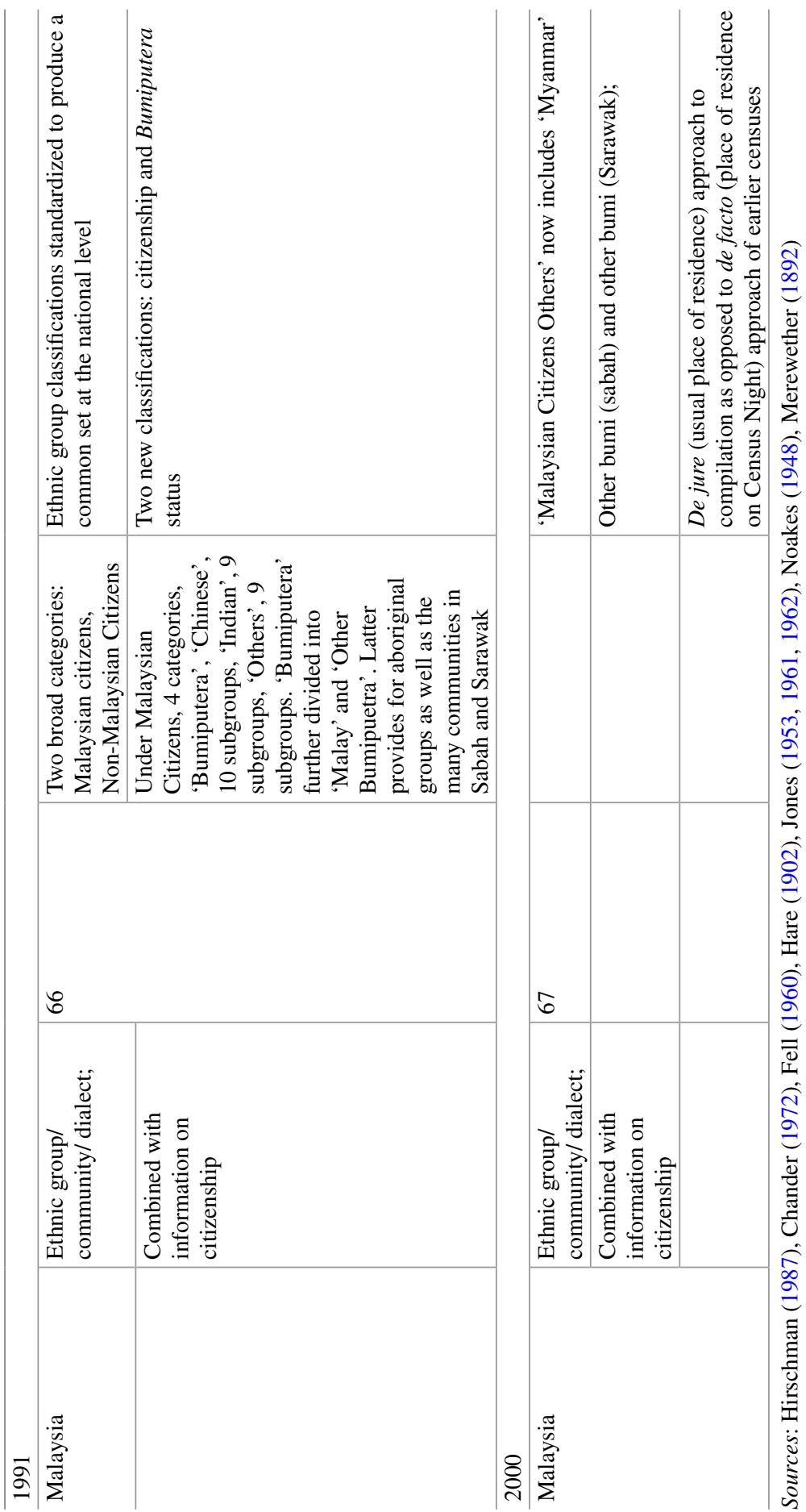




\section{Appendix 8.2: Constitution of Malaysia: Definitions of Ethnicity}

\section{Article 160}

(2) In this Constitution, unless the context otherwise requires, the following expressions have the meanings hereby respectively assigned to them, that is to say -

'Aborigine' means an aborigine of the Malay Peninsula;

'Malay' means a person who professes the religion of Islam, habitually speaks the Malay language, conforms to Malay custom and -

(a) was before Merdeka Day born in the Federation or in Singapore or born of parents one of whom was born in the Federation or in Singapore, or is on that day domiciled in the Federation or in Singapore; or

(b) is the issue of such a person;

\section{Article 161}

(6) In this Article 'native' means-

(a) in relation. to Sarawak, a person who is a citizen and either belongs to one of the races specified in Clause (7) as indigenous to the State or is of mixed blood deriving exclusively from those races; and

(b) in relation to Sabah, a person who is a citizen, is the child or grandchild of a person of a race indigenous to Sabah, and was born (whether on or after Malaysia Day or not) either in Sabah or to a father domiciled in Sabah at the time of the birth.

(7) The races to be treated for the purposes of the definition of 'native' in Clause (6) as indigenous to Sarawak are the Bukitans, Bisayahs, Dusuns, Sea Dayaks, Land Dayaks, Kadayans, Kalabit, Kayans, Kenyags (Including Sabups and Sipengs), Kajangs (including Sekapans,. Kejamans, Lahanans, Punans, Tanjongs dan Kanowits), Lugats, Lisums, Malays, Melanos, Muruts, Penans, Sians, Tagals, Tabuns and Ukits.

Selected from http://www.helplinelaw.com/law/constitution/malaysia/ malaysia01.php 


\section{Appendix 8.3: Areas in Which Special Privileges May be Provided}

\section{Article 153 of the Constitution}

(1) It shall be the responsibility of the Yang di-Pertuan Agong to safeguard the special position of the Malays and natives of any of the States of Sabah and Sarawak and the legitimate interests of other communities in accordance with the provisions of this Article.

(2) Notwithstanding anything in this Constitution, but subject to the provisions of Article 40 and of this Article, the Yang di-Pertuan Agong shall exercise his functions under this Constitution and federal law in such manner as may be necessary to safeguard the special provision of the Malays and natives of any of the States of Sabah and Sarawak and to ensure the reservation for Malays and natives of any of the States of Sabah and Sarawak of such proportion as he may deem reasonable of positions in the public service (other than the public service of a State) and of scholarships, exhibitions and other similar educational or training privileges or special facilities given or accorded by the Federal Government and, when any permit or licence for the operation of any trade or business is required by federal law, then, subject to the provisions of that law and this Article, of such permits and licences.

(4) In exercising his functions under this Constitution and federal law in accordance with Clauses (1) to (3) the Yang di-Pertuan Agong shall not deprive any person of any public office held by him or of the continuance of any scholarship, exhibition or other educational or training privileges or special facilities enjoyed by him.

\section{References}

Andaya, B. W., \& Andaya, L. Y. (1982). A history of Malaysia. London: Macmillan.

Callister, P. (2006). Ethnic measurement as a policy-making tool. In E. Rata \& R. Openshaw (Eds.), The politics of ethnic, boundary-making (pp. 142-155). Basingstoke/New York: Palgrave Macmillan.

Callister, P., Didham, R., \& Potter, D. (2006). Measuring ethnicity in New Zealand: Developing tools for social analysis. Paper presented at the Population Association of America Annual Meeting. PAA meeting, March 31-April 1, Los Angeles: California.

Chan, K. E., \& Tey, N. P. (2000). Demographic processes and change. In K. H. Lee \& C. B. Tan (Eds.), The Chinese in Malaysia (pp. 71-90). Kuala Lumpur: Oxford University Press.

Chander, R. (1972). 1970 population and housing census: Community groups. Kuala Lumpur: Department of Statistics, Malaysia.

Chander, R. (1977). General report of the population census of Malaysia, 1970. Kuala Lumpur: Department of Statistics, Malaysia.

Cheong, K. C., Nagaraj, S., \& Lee, K. H. (2009). Counting ethnicity: The new economic policy and social integration. Malaysian Journal of Economic Studies, 46(2), 33-52. 
Department of Statistics, Malaysia. (2001a). Population and housing census of Malaysia, 2000: Population distribution and basic demographic characteristics. Putrajaya: Department of Statistics, Malaysia.

Department of Statistics, Malaysia. (2001b). Vital statistics: Time series Malaysia, 1963-1998. Putrajaya: Department of Statistics, Malaysia.

Department of Statistics, Malaysia. (2005). Population and housing census of Malaysia, 2000: General report of the population and housing census. Putrajaya: Department of Statistics, Malaysia.

Fell, H. (1960). 1957 population census of the Federation of Malaya, report no. 14. Kuala Lumpur: Department of Statistics.

Hare, G. T. (1902). Federated Malay States: Census of the population. Kuala Lumpur: Government Printer.

Hirschman, C. (1987). The meaning and measurement of ethnicity in Malaysia: An analysis of census classifications. Journal of Asian Studies, 46(3), 555-582.

Hirschman, C. (1993). How to measure ethnicity: An immodest proposal. In Challenges on measuring an ethnic world science, politics and reality (pp. 547-560). Washington, DC: U. S. Government Printing Office/Statistics Canada and U. S. Bureau of the Census.

Jones, L. W., Superintendent of Census, North Borneo. (1953). A report on the census of population held on 4th June, 1951. London, Government of the Colony of North Borneo.

Jones, L. W., Superintendent of Census, North Borneo. (1961). A report on the census of population held on 10th August, 1960. London: Government of the Colony of North Borneo.

Jones, L. W., Superintendent of Census, Sarawak. (1962). Report on the census of population taken on 15th June, 1960. Kucing: Government Printer.

Khoo, T. H. (1983). General report of the population census of Malaysia, 1980. Kuala Lumpur: Department of Statistics, Malaysia.

Merewether, E. M., Superintendent of Census. (1892). Report on the census of the Straits Settlements taken on 5th April, 1891. Singapore: Government Printing Office.

Morning, A. (2008). Ethnic classification in global perspective: A cross-national survey of the 2000 census round. Population Research and Policy Review, 27(2), 239-272.

Nagaraj, S. (2009). Intermarriage in Malaysia. Malaysian Journal of Economic Studies, 46(2), 75-92.

Nagaraj, S., \& Lee, K. H. (2003). Human resource development and social reengineering: Which part of the field are we levelling? In J. Yahaya, N. P. Tey, \& K. K. Yeoh (Eds.), Sustaining growth, enhancing distribution: The NEP and NDP revisited (pp. 16-70). Kuala Lumpur: Centre for Economic Development and Ethnic Relations, University of Malaya.

Nicholas, C. (2004). The Orang Asli: First on the land, last in the plan. In R. Mason \& A. S. M. Omar (Eds.), The 'Bumiputera policy': Dynamics and dilemmas, special issue of Kajian Malaysia: Journal of Malaysian Studies, 21(1/2), 315-329. Kajian Malaysia: Journal of Malaysian Studies.

Noakes, J. L., Superintendent of Census of Sarawak and Brunei. (1948). A report on the 1947 population census. Kucing: Government Printer.

Rae, D. W., \& Taylor, M. (1970). The analysis of political cleavages. New Haven: Yale University Press.

Saw, S. H. (1968). Malayan economic statistics. Kuala Lumpur: Faculty of Economics and Administration, University of Malaya.

Sawyer, T. (1998). Measuring race and ethnicity: Meeting public policy goals. http://www.amstat. org/publications/tas/index.cfm?fuseaction=sawyer1998 
Tan, P. C. (1986). The Study on marriage and marital dissolution in Peninsular Malaysia. Kuala Lumpur: Faculty of Economics and Administration, University of Malaya.

United Nations Statistics Division. (2003). Ethnicity: A review of data collection and dissemination. New York: Demographic and Social Statistics Branch, United Nations Statistical Division.

Yeoh, K. K. (2001). Towards an index of ethnic fractionalization (Working Paper Series 3). Kuala Lumpur: Faculty of Economics and Administration, University of Malaya. Available at SSRN: http://ssrn.com/abstract=2128337 or http://dx.doi.org/10.2139/ssrn.2128337

Yinger, J. M. (1986). Intersecting strands in the theorisation of race and ethnic relations. In J. Rex $\&$ D. Mason (Eds.), Theories of race and ethnic relations (pp. 20-41). Cambridge: Cambridge University Press. 